\title{
SHRIMP U-Pb zircon dating of the Ordos Basin basement and its tectonic significance
}

\author{
HU JianMin ${ }^{1 *}$, LIU XinShe ${ }^{2}$, LI ZhenHong ${ }^{1}$, ZHAO Yue ${ }^{1}$, ZHANG ShuanHong ${ }^{1}$, \\ LIU XiaoChun ${ }^{1}$, QU HongJie ${ }^{1} \&$ CHEN Hong ${ }^{1}$ \\ ${ }^{1}$ Institute of Geomechanics, Chinese Academy of Geological Sciences, Beijing 100081, China; \\ ${ }^{2}$ Research Institute of Exploration and Development of Changqing Oilfield Company, PetroChina, Xi'an 710018, China
}

Received March 7, 2012; accepted May 8, 2012; published online July 16, 2012

\begin{abstract}
SHRIMP U-Pb zircon ${ }^{207} \mathrm{~Pb} /{ }^{206} \mathrm{~Pb}$ ages were obtained from two drill cores from the basement of the Ordos Basin. A garnet-sillimanite-biotite-plagioclase gneiss (QI1-1) from the western Ordos Basin basement yielded an average age of $2031 \pm 10 \mathrm{Ma}$. Based on the mineral assemblages, the source material of the gneiss is speculated to be pelitic-felsic system. A gneissic two-mica granite (Long1-1) from the eastern Ordos Basin basement yielded an average age of 2035 \pm 10 Ma. The zircons from both samples exhibit magmatic growth pattern. The shapes of the zircons suggest that the zircons should crystallize from a granitic of felsic volcanic terrain. The ages and the characters of zircons are consisitent with the other researches in the Ordos Basin and indicate that the basement of the Ordos Basin had experienced an intensive magmatic epsode during the late Paleoproterozoic period. The date from this study suggest the possible existences of a Paleoproterozoic mobile tectonic belt in the region. The reconstruction of such a belt is critical for understanding the tectonomagmatic evolution of the western block of the North China Craton.
\end{abstract}

North China Craton, Ordos Basin, metamorphic rock, granite, U-Pb age of zircon, Paleoproterozoic

Citation: Hu J M, Liu X S, Li Z H, et al. SHRIMP U-Pb zircon dating of the Ordos Basin basement and its tectonic significance. Chin Sci Bull, 2013, 58: 118-127, doi: 10.1007/s11434-012-5274-0

The Ordos Basin is situated at the western North China Craton. The Basin consists primarily of metamorphic basement rocks overlain by a thick sequence of Mesozoic and Paleozoic covering sedimentary rocks [1]. The basement features within the Ordos Basin have been studied by gravity and magnetic surveys, as well as ground-based geological mapping of outcrops within and adjacent to the basin [2-5]. Drillings in the Ordos Basin have confirmed that the basin consists of granulite metamorphic basement [6]. Previous geochronological information related to the basement in this region was based primarily on last century $\mathrm{Rb}-\mathrm{Sr}$ isochronous age of $1.8 \mathrm{Ga}$ [7-9].

In recent years, the tectonic reconstruction of north China has created a new interpretation for the early evolution of the North China Craton. Due to a lack of geochemistry, petrology, and geochronology data of the Ordos Basin base-

\footnotetext{
*Corresponding author (email: jianminhu@vip.sina.com)
}

ment rocks, an understanding of the pre-Cambrian evolution of the North China Craton was still sifficult and controversial $[10,11]$. Some researchers suggested that the region collided with the Yinshan block at about $\sim 1.95 \mathrm{Ga}$, which led to the formation of the Helanshan-Wulashan Khondalite belt in the northwestern part of the North China Craton [12]. The collision of the western and the eastern blocks within the North China Craton led to the Trans-north China orogen [1,12-15]. Subsequent researches concluded that the North China Craton had experienced compressional events between $22.0-1.97 \mathrm{Ga}$ which led to the closure of intracontinental basins. This sequence of events led to the formation of three Paleoproterozoic mobile belts; Jiaoliao Belt (eastern North China Craton), Jinyü Belt (central North China Craton) and Fengzhen Belt (northwestern part of North China Craton). The distribution, deformation, and metamorphism characters of these mobile belts indicate they had experienced complete orogenic cycle (uplifting- 
subduction-collision), which is similar to a modern continent-continent collisional orogen $[11,16,17]$.

In this paper, we present new U-Pb zircon ages for rocks from two drilling holes within the Ordos Basin. The zircon $\mathrm{U}-\mathrm{Pb}$ ages were collected using SHRIMP-II in Beijing SHRIMP center. This new geochronological information from the basement rocks of the Ordos Basin is important for understanding the tectonomagmatic evolution of the North China Craton.

\section{Sample location and rock characters}

Based on geophysical data and drill- hole information, it has been interpreted that Ordos Basin contains three northeastward-extending Meso-Neoproterozoic sedimentary sags. In the Eastern block between Yan'an and Huanxian, there are two northeast-ward-extending basement faults, Huanxian-Hengshan fault (HHF) and Huachi-Datong fault (HDF) (Figure 1). Two samples were collected from the basement drill cores. Sample QI1-1 was collected from drill hole QI1 at the meso-Neoproterozoic deep sag of the east Ordos Basin, to the southeast of Shizuishan City, about $80 \mathrm{~km}$ from the west Khondalite Belt. Sample Long1-1 was collected from drill hole Long1 located between HHF and HDF to the southeast of Yulin City, about $120 \mathrm{~km}$ away from Lüliang Mountains. Both samples were the basement rocks from the basin.

Drill hole QI1 had a finished depth of $5233.0 \mathrm{~m}$, the penetrated basement thickness was $233.0 \mathrm{~m}$ in this hole, and the sample was collected at the depth of $5135 \mathrm{~m}$ (Figure 2). The strata from top to bottom included: the lower Triassic Liujiagou Fm, the upper Permian Shiqianfeng Fm, the middle Permian Shihezi Fm, the lower Permian Shanxi Fm and Taiyuan Fm, the Carboniferous Benxi Fm, the middle Ordovician Wulalike Fm, the lower Ordovician Kelimoli Fm, Zhuozishan Fm and Sandaokan Fm, the upper Cambrian Sanshanzi Fm, the middle Cambrian Zhangxia Fm and Xuzhuang Fm, and the Paleoproterozoic Helanshan Group. There were hiatus from the late Ordovician to the Devonian, and from the Mesoproterozoic to the early Cambrian. The middle Cambrian Xuzhuang Fm, calcareous mudstone at top and calcareous dolomite at bottom, directly contacted with the basement metamorphic rocks.

Drill hole Long1 had a finished depth of $3580.0 \mathrm{~m}$, penetrated basement thickness was $233.0 \mathrm{~m}$, and the sample was collected at the depth of $3495 \mathrm{~m}$ (Figure 2). The strata from top to bottom included: the middle Triassic Zhifang Fm, the lower Triassic Shanggou Fm and Liujiagou Fm, the upper Permian Shiqianfeng Fm, the middle Permian Shihezi Fm,

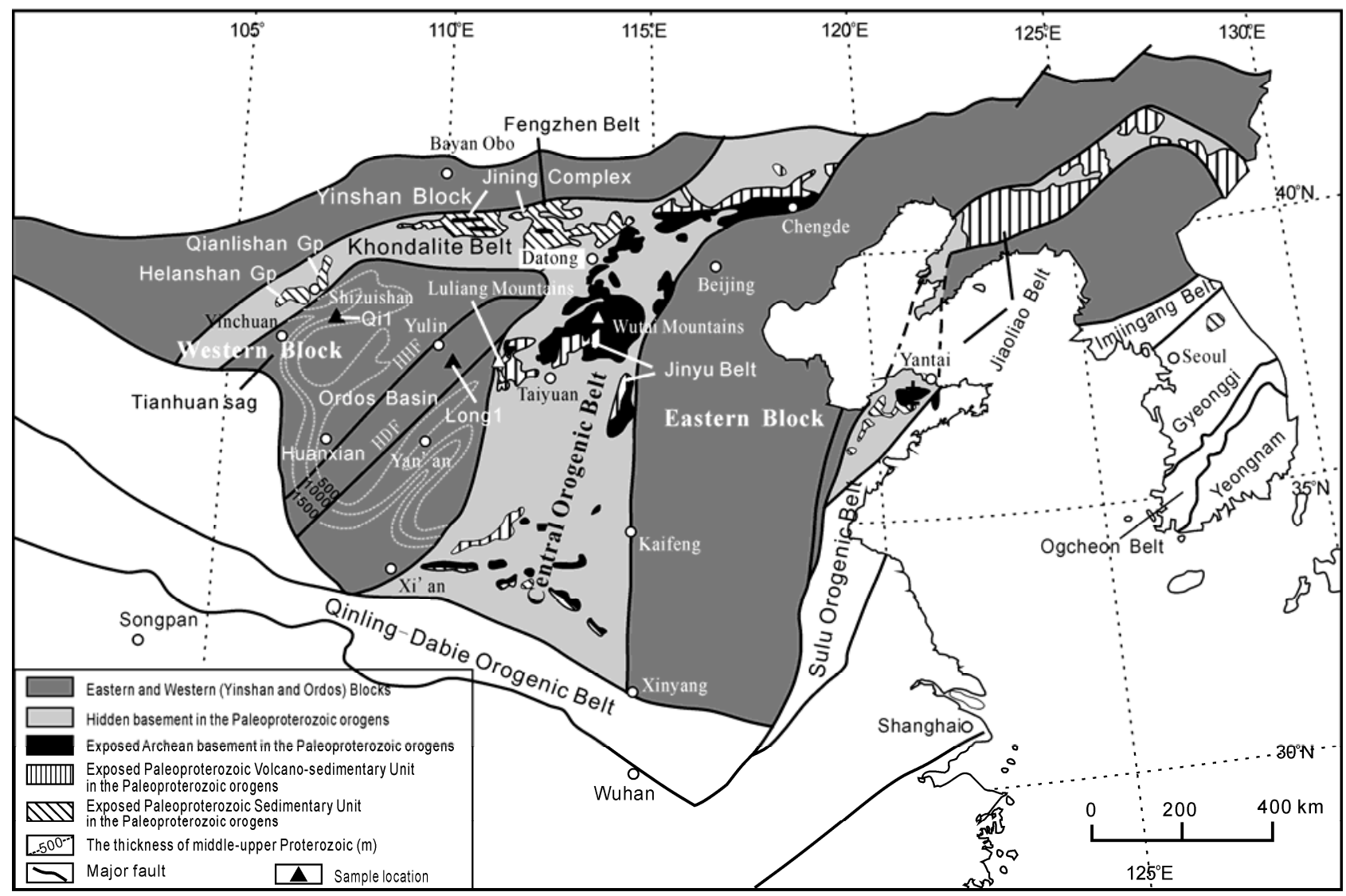

Figure 1 Precambrian tectonic framework of the North China Craton (modified from $[2,10,18]$ ). HHF-Huanxian-Hengshan fault, HDF-Huachi-Datong fault, Gp-Group, QI1-western drill hole, Long1-eastern drill hole. 


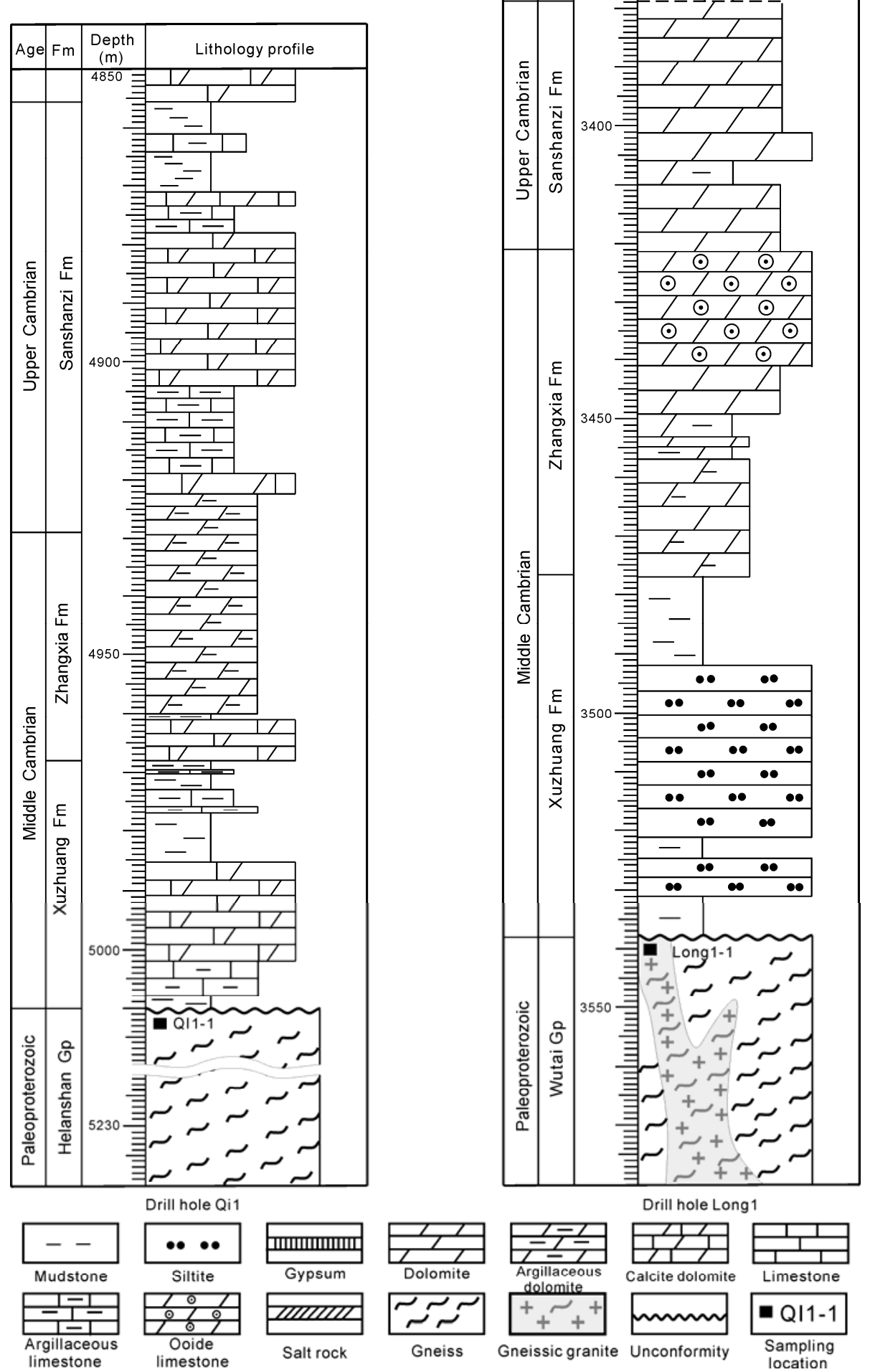

Figure 2 Basement columnar sections of drill-hole QI1 and Long1 in the Ordos basin Solid squares show sample locations. Solid squares are the sample locations of the drill core. There are absence of Meso-Neoproterozoic strata in both QI1 and Long1 drill holes. 
the lower Permian Shanxi Fm and Taiyuan Fm, the Carboniferous Benxi Fm, the lower Ordovician Majiagou Fm, the upper Cambrian Sanshanzi Fm, the middle Cambrian Zhangxia Fm and Xuzhuang Fm, and the Paleoproterozoic Group. There were hiatus of the middle Ordovician to the Devonian and the Mesoproterozoic to the early Cambrian. The middle Cambrian Xuzhuang Fm, which is composed of pelitic dolomite, dolomitic pelite, mudstone and pelitic silt-stone, lies directly on metamorphic rocks of basement. The two drill holes show consistency in strata deficiency and present good matches in stratigraphic sequences.

Sample QI1-1 is aluminum-rich gneiss, composed of sillimanite $(10 \%)$, garnet $(5 \%)$, biotite $(5 \%)$, plagioclase $(40 \%)$, K-feldspar $(5 \%)$ and quartz $(35 \%)$. It has granular blastic texture and gneissic structure (Figure $3 \mathrm{a}-\mathrm{f}$ ). Quartz has two different shapes, the irregular grain and the elongated or ribbon-like grain. The elongated quartzes are characterized by obvious undulating extinction, and coexisting with biotite and sillimanite to form foliation (Figure 3a,b).
Plagioclases are also showing irregular granular or elongated tabulate grains, the microstructure of the dense lamella show plastic deformation (Figure 3e,f). Garnets are mostly irregular grains, contain rounded quartz, plagioclase and biotite inclusions (Figure 3c,d). Some big garnets are elongated, have a length to width ratio up to $6: 1$, suggesting the experience of plastic deformation (Figure 3c,d).

Sample Long1-1 is two-mica granitic gneiss, consisting quartz $(35 \%)$, plagioclase $(25 \%)$, K-feldspar (35\%), biotite $(3 \%)$, and muscovite $(2 \%)$ (Figure $3 \mathrm{~g}-\mathrm{i})$. Biotites and muscovites distribute among the elongated quartze grains and form foliation (Figure 3g,h). Feldspars are granular or elongated tabular shape, with grain size up to $3 \mathrm{~mm}$, and show weak sericitization. The rock contains schist enclaves which are composed with sillimanite $(40 \%)$, biotite $(30 \%)$, muscovite $(15 \%)$, plagioclase and quartz $(15 \%)$, and minor Ti-Fe oxide. The schist enclaves are clearly different from its granite host in lithology, but similar to the gneiss sample from drill-hole QI1. The enclaves are defined as the relicts
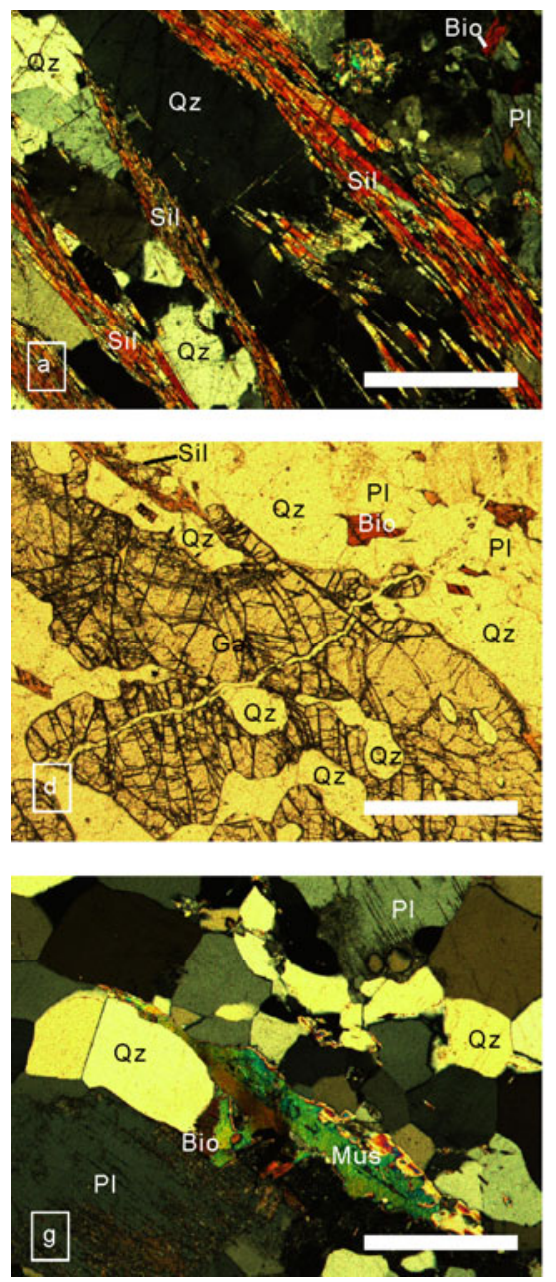
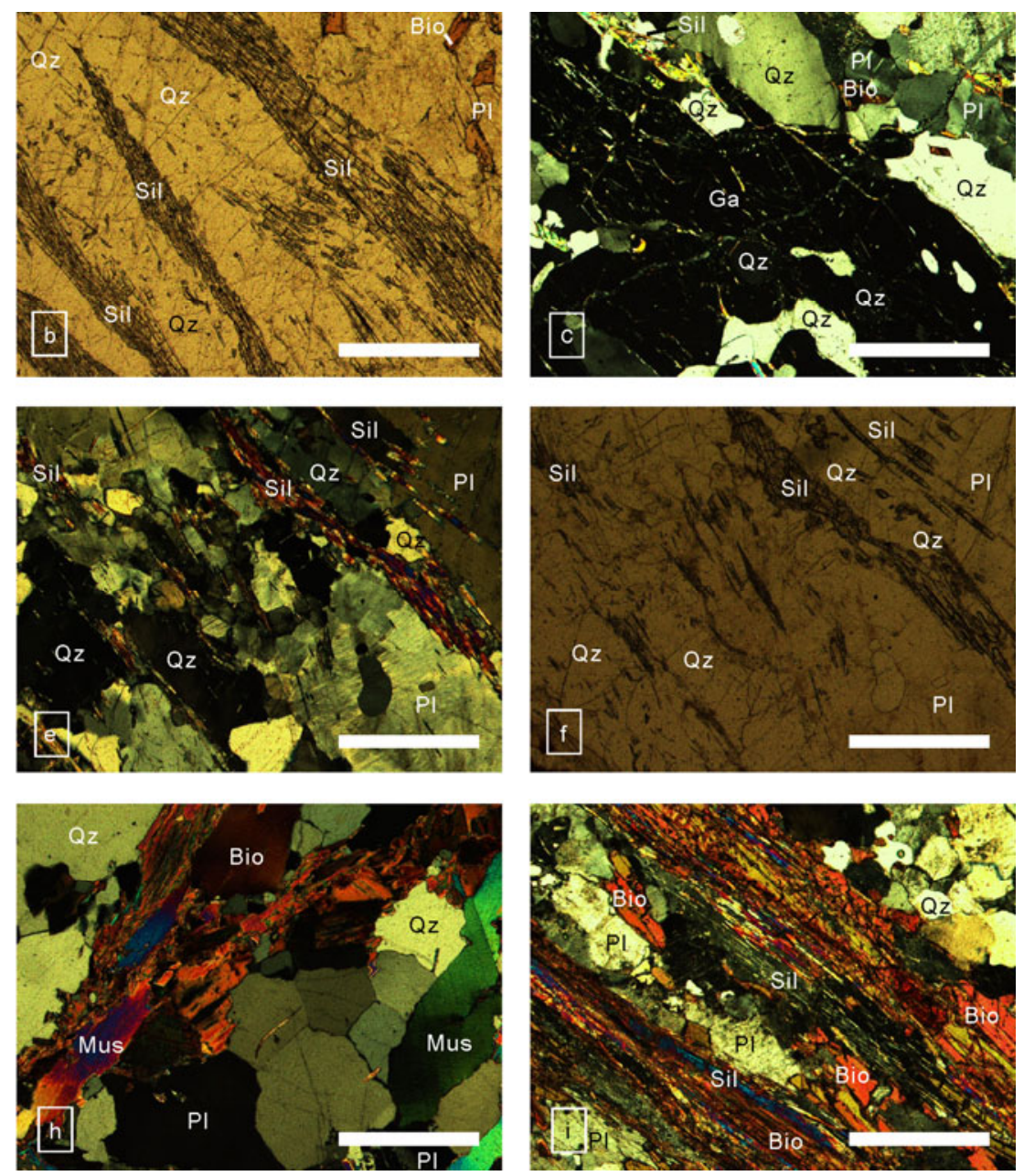

Figure 3 Microphotograph of basement metamorphic rock and granitic gneiss from the Ordos Basin. a-f are from sample QI1-1, garnet-sillimanite-biotite plagioclase gneiss, in which the quartz grains form bands and the garnets show elongate shape; g-i are from sample Long1-1, two-mica granitic gneiss, in which sillimanite-biotite schists show as enclaves. Scale bars: $200 \mu \mathrm{m}$. b, d, and f are plain-polarized image, others are cross-polarized image. Bio-biotite, Ga-garnet, Mus-muscovite, Pl-plagioclase, Qz-quartz, Sil-sillimanite. 
of S-type granite source rock or metapelite captured during the granite intrusion (Figure 3i).

\section{Analytical technique}

Analyses of zircon U-Th-Pb isotopic compositions were obtained using a high sensitivity, high resolution ion probe (SHRIMP II) at the Beijing SHRIMP Center, Chinese Academy of Geological Sciences. Zircon separations were carried out at the Langfang Rock-mineral Preparation Laboratory of Hebei Geological Survey Bureau. The zircons were concentrated after the separation procedure including electromagnetic separation and heavy liquid separation. The preconcentrates were handpicked using a binocular microscope. The selected zircon grains, together with standard zircons (TEM with standard age of $417 \mathrm{Ma}$ ), were mounted in epoxy resin to make 1" discs and then polished at Beijing SHRIMP Center. Before SHRIMP analysis, reflected light and transmitted light microphotographs, cathodoluminescence (CL), and backscatter electronic (BSE) images were collected for the study of the zircon characterization. Then the mounts were cleaned and gold coated. The U-Th-Pb analyses were performed on SHRIMP II ion probe with the following condition [19-21]: spot size $20 \mu \mathrm{m}$, acceleration voltage $10 \mathrm{kV}$, and the primary $\mathrm{O}^{2-}$ ion beam current $4.5 \mathrm{nA}$. Mass resolution was ca. 5400 at $1 \%$ peak height. The data were collected in sets of five scans throughout the $\mathrm{Zr}, \mathrm{Pb}, \mathrm{U}$ and Th isotope species. Between every two or three analyses, a reference zircon was tested for standard correction. Ages and concordia diagrams were calculated using the programs SQUID 1.03d [22] and ISOPLOT 3.23 [23]. Common Pb was corrected by the measured ${ }^{204} \mathrm{~Pb}$. Correction for Common $\mathrm{Pb}$ of standard sample and analysed sample was determined by $417 \mathrm{Ma}$ model of Stacey et al. [24]: ${ }^{207} \mathrm{~Pb} /{ }^{206} \mathrm{~Pb}=0.864$, ${ }^{208} \mathrm{~Pb} /{ }^{206} \mathrm{~Pb}=2.097,{ }^{206} \mathrm{~Pb} /{ }^{204} \mathrm{~Pb}=18.052$.

\section{Analytical results}

The zircons from Samples QI1-1 and Long1-1 are basically consistent in shape. Nearly all the zircons contain cracks and inclusions. The zircons generally have dark honey color, elliptical and round cylindrical shape, and some grains exhibit simple tetragonal dipyramid and ditetragonal dipyramid forms. The zircon grains have average 60-80 $\mu \mathrm{m}$ in length, but a few grains had length up to $150 \mu \mathrm{m}$. Zircon diameters generally ranged from $30-50 \mu \mathrm{m}$. Cathodoluminesence (CL) images show the presence of rhythm zoning that suggests a magmatic origin. Some zircons from Sample QI1-1 have narrow growth rims, which should grew during regional metamorphism. Some zircons do not show clear internal structure because of their weak luminescence (Figure 4).

Seventeen individual spot ages from the cores of zircon grains and three rim spots of the zircons were analyzed for Sample QI1-1 (Figure 4, Table 1). The zircons have 76-375 ppm $\mathrm{U}$ and $21-152 \mathrm{ppm} \mathrm{Th}$. Th/U ratio ranges among 0.15-0.62 (except spot 5.2). The whole data sets show a character of magmatic origin. In spite of obvious $\mathrm{Pb}$ lost for several analyses, the data generally plot on concordia line and suggest a consistent forming age. The 17 individual spot ages yielded an upper intersection point age of $2045 \pm 19 \mathrm{Ma}(\mathrm{MSWD}=1.5)$, and $\mathrm{a}{ }^{207} \mathrm{~Pb} /{ }^{206} \mathrm{~Pb}$ weighted average age of $2031 \pm 10 \mathrm{Ma}(\mathrm{MSWD}=1.6 \mathrm{Ma})$. The other 3 analytic spots were on the metamorphic rims (points 13.1, 14.1 and 18.1). In contrast with the data from zircon cores, the three data from rims had higher U content $(904,802$ and $592 \mathrm{ppm})$ and lower Th content (30, 23 and $68 \mathrm{ppm})$, with the $\mathrm{Th} / \mathrm{U}$ ratio less than $0.12(0.03,0.03$ and 0.12$)$. The data represent a metamorphic zircon characters. Because of higher $\mathrm{U}$ contents, the $\mathrm{Pb}$ lost was more obvious. The three data yielded the ${ }^{207} \mathrm{~Pb} /{ }^{206} \mathrm{~Pb}$ ages of $1625 \pm 17 \mathrm{Ma}, 1680 \pm 23$ Ma and 1847 \pm 24 Ma (Table 1).

Twenty zircon grains were analyzed from Sample Long1-1 (Figures 4, 6, Table 2). The zircons have 111-604 ppm U, 28-498 ppm Th, and $\mathrm{Th} / \mathrm{U}$ ratios of $0.13-1.42$. They also show the magmatic zircon characters. Points 9.1, 13.1, 15.1 and 19.1 had obvious Pb lost, also the data from $5.1,16.1$ and 18.1 deviated from the accordance line. Getting rid of the 7 points, the other 13 analytic dots yielded an upper intersection point age of $2045 \pm 16 \mathrm{Ma}(\mathrm{MSWD}=1.3)$, consisting with the ${ }^{207} \mathrm{~Pb} /{ }^{206} \mathrm{~Pb}$ weighted average age of QI1-1 (2035 $\pm 10 \mathrm{Ma}, \mathrm{MSWD}=1.4)$ in the error range (Figure 6, Table 2).

\section{Discussion}

The two drill core samples are respectively garnet-sillimanite-biotite-plagioclase gneiss (Sample QI1-1) and twomica granitic gneiss (Sample Long1-1) from the basement of Ordos Basin. They are very different from each other in lithology, but very consistent in ages. Zircon morphology and their CL images clearly indicate the magmatic origin of the zircons from both samples. Most of zircons from Sample QI1-1 have narrow metamorphic accreted rim. Both samples have the magmatic age of about 2035 Ma. Sample QI1-1 zircon rims give a metamorphic age of about 1850 Ma. However, the QI1-1, which contains sillimanite, garnet, biotite, plagioclase and quartz, is a typical aluminum-rich paragneiss and should form from a sedimentary rock. The magmatic zircon character and the ages from zircon cores should originate from source material supplying the sedimentary process. The regional studies indicate that those zircons were inherited from the Paleoproterozoic granites or volcanic-sedimentary rocks. Three age data from metamorphic rims of zircons from Sample QI1-1 provide the information of metamorphic age. However, the metamorphic zircon rims are pretty narrow, and the ion beam size for 

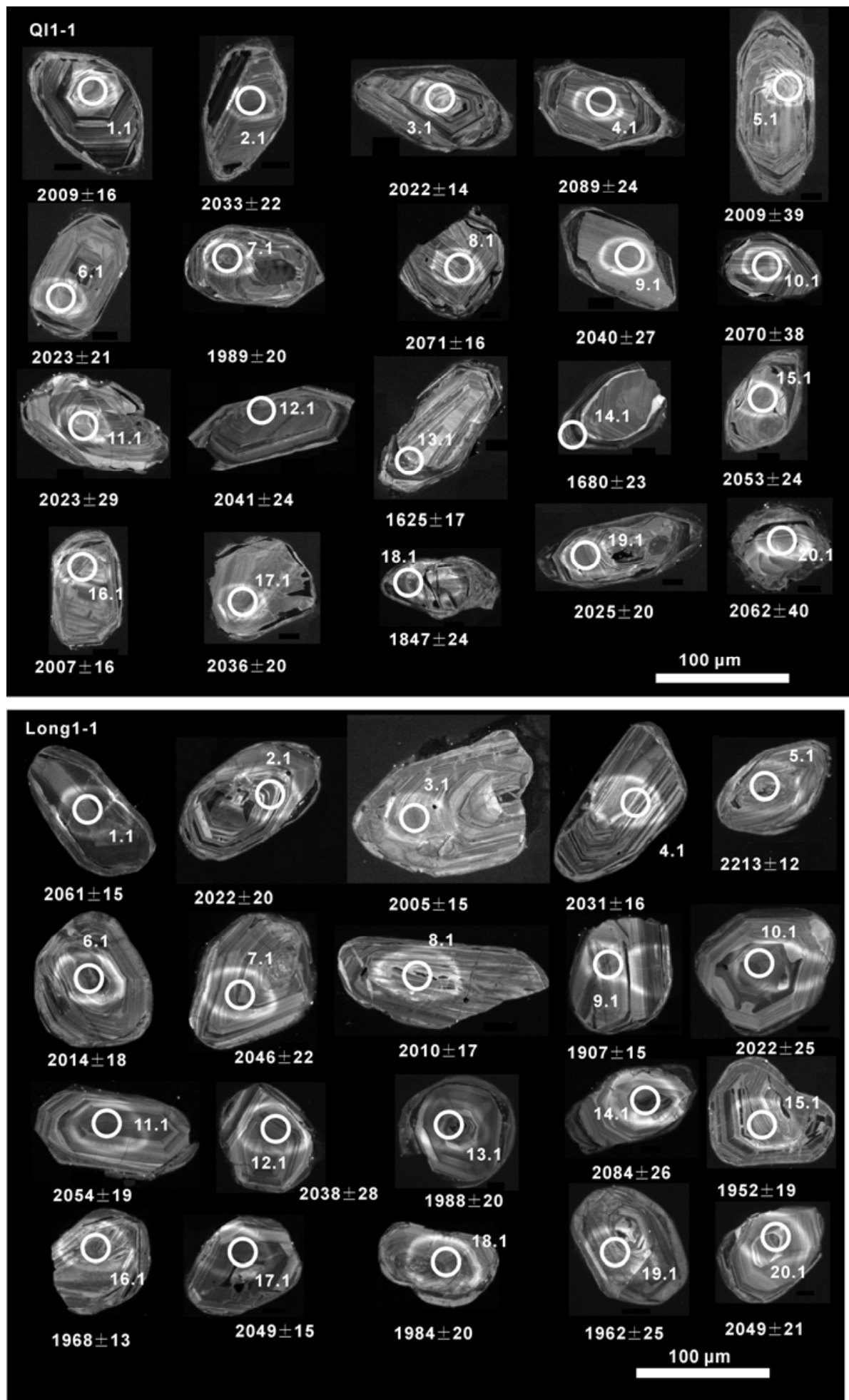

Figure 4 Cathodoluminesence (CL) images for zircons from QI1-1 and Long1-1. Apparent U-Pb ages are listed under each grain and the ion probe spot number is listed inside each grain.

SHRIMP is around $20 \mu \mathrm{m}$, it is super difficult to collect accurate rim age without interference from the core material. Only three spots were picked for analyses. Sample Long1-1is granitic gness containing schist enclaves. The sillimanite-biotite schist in Long1-1 should be captured during the intrusion of the two-mica granite and before the metamorphism. In other words, the enclave capture should take place at the magmatic event of $2035 \mathrm{Ma}$. The $1850 \mathrm{Ma}$ metamorphism altered both the Long1-1 granite and its pelitic enclaves and lineation structures in both the granite and 
Table 1 SHRIMP U-Pb analyses of zircons for garnet-sillimanite-biotite-plagioclase gneiss (Sample QI1-1) from drill hole QI1 at western Ordos Basin

\begin{tabular}{|c|c|c|c|c|c|c|c|c|c|c|c|}
\hline \multirow{2}{*}{ Spot } & \multirow{2}{*}{$\begin{array}{c}{ }^{206} \mathrm{~Pb}_{\mathrm{c}} \\
(\%)\end{array}$} & \multirow{2}{*}{$\begin{array}{c}\mathrm{U} \\
(\mathrm{ppm})\end{array}$} & \multirow{2}{*}{$\begin{array}{c}\text { Th } \\
(\mathrm{ppm})\end{array}$} & \multirow{2}{*}{${ }^{232} \mathrm{Th} /{ }^{238} \mathrm{U}$} & \multirow{2}{*}{$\begin{array}{l}{ }^{206} \mathrm{~Pb}^{*} \\
\text { (ppm) }\end{array}$} & \multicolumn{3}{|c|}{ Age (Ma) } & \multicolumn{3}{|c|}{ Isotopic ratios } \\
\hline & & & & & & ${ }^{206} \mathrm{~Pb} /{ }^{238} \mathrm{U}$ & ${ }^{207} \mathrm{~Pb} /{ }^{206} \mathrm{~Pb}$ & ${ }^{208} \mathrm{~Pb} /{ }^{232} \mathrm{Th}$ & ${ }^{207} \mathrm{~Pb}^{*} /{ }^{206} \mathrm{~Pb}^{*}$ & ${ }^{207} \mathrm{~Pb}^{*} /{ }^{235} \mathrm{U}$ & ${ }^{206} \mathrm{~Pb} * /{ }^{238} \mathrm{U}$ \\
\hline 1.1 & 0.33 & 76 & 42 & 0.15 & 86.6 & $1911 \pm 25$ & $2009 \pm 16$ & $1825 \pm 88$ & $0.1236 \pm 0.91$ & $5.88 \pm 1.8$ & $0.3450 \pm 1.5$ \\
\hline 2.1 & 0.19 & 109 & 86 & 0.36 & 79.2 & $2034 \pm 26$ & $2033 \pm 22$ & $2009 \pm 47$ & $0.1253 \pm 1.2$ & $6.41 \pm 2.0$ & $0.3710 \pm 1.5$ \\
\hline 3.1 & 0.18 & 114 & 92 & 0.27 & 92.4 & $1695 \pm 22$ & $2022 \pm 14$ & $1554 \pm 40$ & $0.1245 \pm 0.81$ & $5.16 \pm 1.7$ & $0.3007 \pm 1.5$ \\
\hline 4.1 & 0.29 & 115 & 38 & 0.36 & 34.0 & $1989 \pm 30$ & $2089 \pm 24$ & $1872 \pm 66$ & $0.1294 \pm 1.4$ & $6.45 \pm 2.2$ & $0.3615 \pm 1.8$ \\
\hline 5.1 & 1.68 & 129 & 18 & 0.04 & 117 & $1616 \pm 21$ & $2009 \pm 39$ & $2086 \pm 910$ & $0.1236 \pm 2.2$ & $4.86 \pm 2.6$ & $0.2849 \pm 1.5$ \\
\hline 6.1 & 0.29 & 136 & 51 & 0.35 & 46.3 & $1963 \pm 35$ & $2023 \pm 21$ & $1974 \pm 65$ & $0.1246 \pm 1.2$ & $6.12 \pm 2.4$ & $0.3560 \pm 2.1$ \\
\hline 7.1 & 0.31 & 151 & 34 & 0.19 & 60.4 & $2030 \pm 28$ & $1989 \pm 20$ & $2036 \pm 100$ & $0.1222 \pm 1.1$ & $6.24 \pm 2.0$ & $0.3701 \pm 1.6$ \\
\hline 8.1 & 0.28 & 152 & 139 & 0.54 & 79.5 & $1904 \pm 25$ & $2071 \pm 16$ & $1778 \pm 37$ & $0.1280 \pm 0.89$ & $6.07 \pm 1.7$ & $0.3436 \pm 1.5$ \\
\hline 9.1 & 0.53 & 189 & 68 & 0.62 & 35.7 & $1998 \pm 59$ & $2040 \pm 27$ & $1926 \pm 80$ & $0.1258 \pm 1.5$ & $6.30 \pm 3.8$ & $0.363 \pm 3.4$ \\
\hline 10.1 & 0.97 & 243 & 21 & 0.28 & 23.7 & $1973 \pm 33$ & $2070 \pm 38$ & $1952 \pm 150$ & $0.1279 \pm 2.1$ & $6.31 \pm 2.9$ & $0.3580 \pm 1.9$ \\
\hline 11.1 & 0.45 & 248 & 35 & 0.32 & 35.6 & $1979 \pm 30$ & $2023 \pm 29$ & $1900 \pm 89$ & $0.1246 \pm 1.6$ & $6.17 \pm 2.4$ & $0.3593 \pm 1.7$ \\
\hline 12.1 & 0.41 & 269 & 53 & 0.43 & 41.7 & $2055 \pm 30$ & $2041 \pm 24$ & $2034 \pm 64$ & $0.1259 \pm 1.4$ & $6.52 \pm 2.2$ & $0.3753 \pm 1.7$ \\
\hline 13.1 & 0.33 & 274 & 30 & 0.03 & 133 & $1019 \pm 14$ & $1625 \pm 17$ & $1094 \pm 160$ & $0.10003 \pm 0.92$ & $2.36 \pm 1.8$ & $0.1712 \pm 1.5$ \\
\hline 14.1 & 0.45 & 291 & 23 & 0.03 & 90.6 & $793 \pm 11$ & $1680 \pm 23$ & $897 \pm 190$ & $0.1031 \pm 1.3$ & $1.86 \pm 1.9$ & $0.1308 \pm 1.4$ \\
\hline 15.1 & 0.55 & 357 & 41 & 0.28 & 48.0 & $2007 \pm 28$ & $2053 \pm 24$ & $1989 \pm 99$ & $0.1268 \pm 1.4$ & $6.38 \pm 2.1$ & $0.3653 \pm 1.6$ \\
\hline 16.1 & 0.27 & 375 & 152 & 0.42 & 95.9 & $1677 \pm 22$ & $2007 \pm 16$ & $1651 \pm 38$ & $0.1235 \pm 0.91$ & $5.06 \pm 1.7$ & $0.2971 \pm 1.5$ \\
\hline 17.1 & 0.29 & 471 & 90 & 0.38 & 77.5 & $2033 \pm 27$ & $2036 \pm 20$ & $1989 \pm 52$ & $0.1255 \pm 1.2$ & $6.41 \pm 1.9$ & $0.3707 \pm 1.5$ \\
\hline 18.1 & 0.51 & 592 & 68 & 0.12 & 94.6 & $1095 \pm 16$ & $1847 \pm 24$ & $1090 \pm 97$ & $0.1129 \pm 1.3$ & $2.88 \pm 2.1$ & $0.1852 \pm 1.6$ \\
\hline 19.1 & 0.32 & 802 & 79 & 0.30 & 77.9 & $1840 \pm 24$ & $2025 \pm 20$ & $1353 \pm 53$ & $0.1247 \pm 1.1$ & $5.68 \pm 1.9$ & $0.3304 \pm 1.5$ \\
\hline 20.1 & 1.80 & 904 & 41 & 0.31 & 39.3 & $1839 \pm 27$ & $2062 \pm 40$ & $2078 \pm 150$ & $0.1274 \pm 2.3$ & $5.80 \pm 2.8$ & $0.3301 \pm 1.7$ \\
\hline
\end{tabular}

a) Errors are $1 \sigma ; \mathrm{Pb}_{\mathrm{c}}$ and $\mathrm{Pb}^{*}$ indicate the common and radiogenic portions, respectively. Error in standard calibration was $0.44 \%$ (not included in above errors but required when comparing data from different mounts). Common $\mathrm{Pb}$ was corrected using the measured ${ }^{204} \mathrm{~Pb}$.

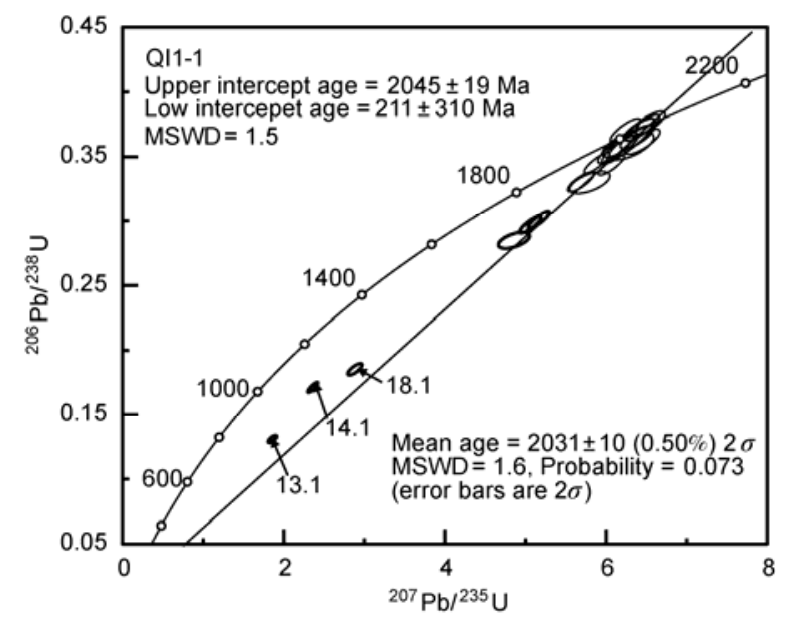

Figure 5 SHRIMP zircon U-Pb concordia for garnet-sillimanite-biotiteplagioclase gneiss (Sample QI1-1) from drill hole QI1 at the western Ordos Basin.

the schist show the same stress character.

Recently, with the development of new chronological techniques, a lot of high quality age data has been collected for the Precambrian terrains in various tectonic units of the North China Craton. The high-grade metamorphic terrain and granitic greenstone at the eastern crustal basements of the North China Craton are mainly with late Archean age; the western TTG gneiss, supracrustal rocks and the Paleo-

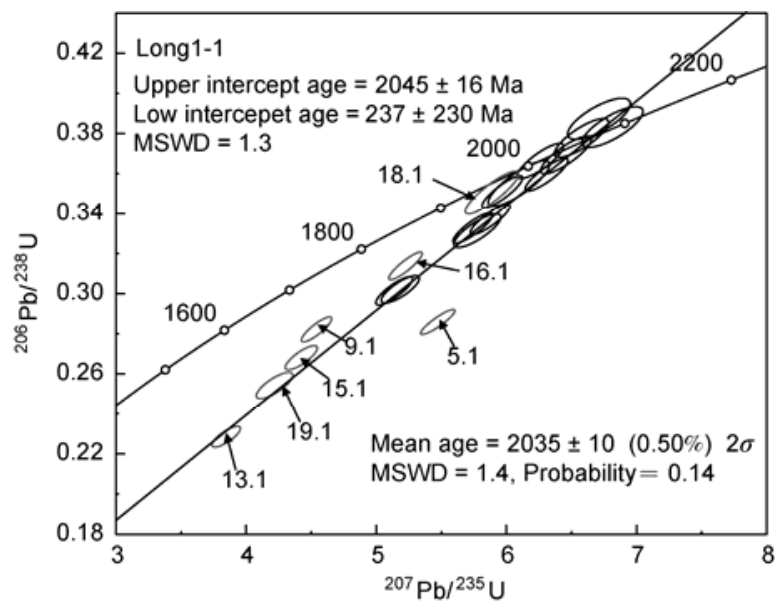

Figure 6 SHRIMP U-Pb zircon concordia diagrams for gneissic twomica granite (Sample Long1-1) from drill hole Long1 at the eastern Ordos Basin.

proterozoic khondalite of North China Craton are formed at the late Archean; and the central orogen of North China Craton is composed of the late Archean to the Paleoproterozoic TTG gneiss, supracrustal rock, mafic dike swarm and syn- or post-tectonic granite. In the previous Archean metamorphic terrain, many blocks of Proterozoic granitic gneiss and supracrustal rocks have been discovered [14,25-35]. The magmatic ages from this research are consistent with 
Table 2 SHRIMP U-Pb analyses of zircons for gneissic two-mica granite (Sample Long1-1) from drill hole Long1 at the eastern Ordos Basin ${ }^{\text {a) }}$

\begin{tabular}{|c|c|c|c|c|c|c|c|c|c|c|c|}
\hline \multirow{2}{*}{ Spot } & \multirow{2}{*}{$\begin{array}{c}{ }^{206} \mathrm{~Pb}_{\mathrm{c}} \\
(\%)\end{array}$} & \multirow{2}{*}{$\begin{array}{c}\mathrm{U} \\
\text { (ppm) }\end{array}$} & \multirow{2}{*}{$\begin{array}{c}\mathrm{Th} \\
\text { (ppm) }\end{array}$} & \multirow{2}{*}{${ }^{232} \mathrm{Th} /{ }^{238} \mathrm{U}$} & \multirow{2}{*}{$\begin{array}{l}{ }^{206} \mathrm{~Pb}^{*} \\
(\mathrm{ppm})\end{array}$} & \multicolumn{3}{|c|}{ Age (Ma) } & \multicolumn{3}{|c|}{ Isotopic ratios } \\
\hline & & & & & & ${ }^{206} \mathrm{~Pb} /{ }^{238} \mathrm{U}$ & ${ }^{207} \mathrm{~Pb} /{ }^{206} \mathrm{~Pb}$ & ${ }^{208} \mathrm{~Pb} /{ }^{232} \mathrm{Th}$ & ${ }^{207} \mathrm{~Pb} *{ }^{206} \mathrm{~Pb}^{*}$ & ${ }^{207} \mathrm{~Pb} * / 235 \mathrm{U}$ & ${ }^{206} \mathrm{~Pb} *{ }^{238} \mathrm{U}$ \\
\hline 1.1 & 0.26 & 278 & 95 & 0.35 & 86.1 & $1980 \pm 26$ & $2061 \pm 15$ & $1892 \pm 46$ & $0.1273 \pm 0.85$ & $6.31 \pm 1.7$ & $0.3595 \pm 1.5$ \\
\hline 2.1 & 0.26 & 303 & 133 & 0.45 & 78.9 & $1702 \pm 22$ & $2022 \pm 20$ & $1621 \pm 35$ & $0.1245 \pm 1.1$ & $5.19 \pm 1.9$ & $0.3021 \pm 1.5$ \\
\hline 3.1 & 0.19 & 291 & 70 & 0.25 & 88.0 & $1939 \pm 25$ & $2005 \pm 15$ & $1826 \pm 52$ & $0.1234 \pm 0.84$ & $5.97 \pm 1.7$ & $0.3510 \pm 1.5$ \\
\hline 4.1 & 0.22 & 251 & 122 & 0.50 & 71.9 & $1852 \pm 24$ & $2031 \pm 16$ & $1689 \pm 35$ & $0.1252 \pm 0.88$ & $5.74 \pm 1.7$ & $0.3327 \pm 1.5$ \\
\hline 5.1 & 0.41 & 604 & 487 & 0.83 & 149 & $1621 \pm 21$ & $2213 \pm 12$ & $1469 \pm 25$ & $0.1389 \pm 0.68$ & $5.47 \pm 1.6$ & $0.2859 \pm 1.4$ \\
\hline 6.1 & 0.19 & 208 & 69 & 0.34 & 65.7 & $2013 \pm 27$ & $2014 \pm 18$ & $2025 \pm 51$ & $0.1239 \pm 1.0$ & $6.26 \pm 1.9$ & $0.3664 \pm 1.6$ \\
\hline 7.1 & 0.54 & 132 & 28 & 0.22 & 43.2 & $2067 \pm 30$ & $2046 \pm 22$ & $1864 \pm 83$ & $0.1262 \pm 1.2$ & $6.58 \pm 2.1$ & $0.3779 \pm 1.7$ \\
\hline 8.1 & 0.33 & 304 & 265 & 0.90 & 79.0 & $1698 \pm 23$ & $2010 \pm 17$ & $1517 \pm 40$ & $0.1237 \pm 0.97$ & $5.14 \pm 1.8$ & $0.3013 \pm 1.5$ \\
\hline 9.1 & 0.24 & 450 & 83 & 0.19 & 109 & $1602 \pm 21$ & $1907 \pm 15$ & $1631 \pm 54$ & $0.1167 \pm 0.86$ & $4.54 \pm 1.7$ & $0.2822 \pm 1.5$ \\
\hline 10.1 & 0.37 & 118 & 31 & 0.27 & 36.2 & $1959 \pm 36$ & $2022 \pm 25$ & $1929 \pm 84$ & $0.1245 \pm 1.4$ & $6.10 \pm 2.6$ & $0.3551 \pm 2.1$ \\
\hline 11.1 & 0.17 & 256 & 134 & 0.54 & 81.4 & $2027 \pm 29$ & $2054 \pm 19$ & $2041 \pm 51$ & $0.1268 \pm 1.1$ & $6.46 \pm 2.0$ & $0.3694 \pm 1.7$ \\
\hline 12.1 & 0.61 & 111 & 78 & 0.72 & 37.2 & $2111 \pm 31$ & $2038 \pm 28$ & $1969 \pm 57$ & $0.1257 \pm 1.6$ & $6.71 \pm 2.4$ & $0.3874 \pm 1.7$ \\
\hline 13.1 & 0.30 & 363 & 498 & 1.42 & 71.4 & $1326 \pm 18$ & $1988 \pm 20$ & $1034 \pm 19$ & $0.1222 \pm 1.1$ & $3.85 \pm 1.9$ & $0.2284 \pm 1.5$ \\
\hline 14.1 & 0.40 & 120 & 66 & 0.57 & 39.8 & $2092 \pm 31$ & $2084 \pm 26$ & $2130 \pm 62$ & $0.1289 \pm 1.5$ & $6.82 \pm 2.3$ & $0.3833 \pm 1.7$ \\
\hline 15.1 & 0.33 & 364 & 207 & 0.59 & 84.1 & $1531 \pm 20$ & $1952 \pm 19$ & $1202 \pm 27$ & $0.1197 \pm 1.1$ & $4.43 \pm 1.8$ & $0.2681 \pm 1.5$ \\
\hline 16.1 & 0.15 & 415 & 54 & 0.13 & 112 & $1759 \pm 22$ & $1968 \pm 13$ & $1544 \pm 56$ & $0.1208 \pm 0.74$ & $5.23 \pm 1.6$ & $0.3138 \pm 1.4$ \\
\hline 17.1 & 0.30 & 324 & 127 & 0.41 & 94.1 & $1873 \pm 24$ & $2049 \pm 15$ & $1743 \pm 40$ & $0.1264 \pm 0.84$ & $5.88 \pm 1.7$ & $0.3371 \pm 1.5$ \\
\hline 18.1 & 0.35 & 215 & 35 & 0.17 & 64.9 & $1937 \pm 34$ & $1984 \pm 20$ & $1766 \pm 97$ & $0.1219 \pm 1.1$ & $5.89 \pm 2.3$ & $0.3505 \pm 2.0$ \\
\hline 19.1 & 0.60 & 259 & 84 & 0.33 & 56.9 & $1460 \pm 22$ & $1962 \pm 25$ & $1215 \pm 55$ & $0.1204 \pm 1.4$ & $4.22 \pm 2.2$ & $0.2542 \pm 1.7$ \\
\hline 20.1 & 0.23 & 149 & 97 & 0.67 & 42.6 & $1845 \pm 27$ & $2049 \pm 21$ & $1775 \pm 59$ & $0.1264 \pm 1.2$ & $5.78 \pm 2.1$ & $0.3314 \pm 1.7$ \\
\hline
\end{tabular}

a) Errors are $1 \sigma ; \mathrm{Pb}_{\mathrm{c}}$ and $\mathrm{Pb} *$ indicate the common and radiogenic portions, respectively. Error in standard calibration was $0.44 \%$ (not included in the above errors but required when comparing data from different mounts). Common $\mathrm{Pb}$ was corrected using the measured ${ }^{204} \mathrm{~Pb}$.

the metamorphism of the north khondalite belt in the western North China Craton. For example, the gneissic granite in Helanshan Group is $2053 \pm 58 \mathrm{Ma}$, the gneissic garnetbearing granite is $2047 \pm 42 \mathrm{Ma}$ [36], the Zhuozishan metamorphosed granite is $2005 \pm 9 \mathrm{Ma}$ [37], the Anziling granite in Liangcheng is 2057 $\pm 19 \mathrm{Ma}$ [38], and the orthogneiss of basement of the Bayan Obo iron ore is $2029 \pm 54 \mathrm{Ma}$ [39]. Two groups of zircon ages have been obtained from graphite-garnet-sillimanite gneiss in Huai'an metamorphic complex situated at the boundary area between the north khondalite belt and the central orogen, the ages from zircon cores are $1946 \pm 26 \mathrm{Ma}$ and $1947 \pm 22 \mathrm{Ma}$, which represent the age of collision between the Ordos basement and the Yinshan block, and the ages from zircon rims are $1850 \pm 15$ $\mathrm{Ma}$ and $1857 \pm 16 \mathrm{Ma}$, which represents the age of collision between the western and the eastern blocks of the North China Craton [40]. Recently, Yin et al. [41,42] reported the 2275-1999 Ma ages from magmatic Qianlishan khondalite, and 1941-1955 Ma ages from metamorphic units based on detrital zircon. The detrital zircons from the Helanshan khondalite gave the 2850-2000 Ma magmatic ages and $\sim 1950$ Ma metamorphic ages. The Jining complex in the east of the khondalite belt has a similar magmatic ages and metamorphic detrital zircon ages $[43,44]$. These ages support our observation and results.

The two samples of this research are far away from each other at a very long distance and are respectively located at the east and west of the Ordos Basin. QI1 locates at the Tianhuan sag in the west part of the Ordos Basin (Figure 1). Drill hole Long1 is at the eastern basin margin and near the Lüliang Mountains at the Central Orogenic Belt. The granitic two-mica gneiss from the Long1 drill hole falls in the same age range as the Proterozoic granites and volcanic rocks of the Wutai Mountain and Lüliang Mountains. This suggests that they formed at the same tectonomagmatic event. For example, the ${ }^{207} \mathrm{~Pb} /{ }^{206} \mathrm{~Pb}$ zircon ages from felsic tuff of Hutuohe metamorphosed volcanic-sedimentary rocks at south Taihuaizhen in the Wutai Mountain are 2180 \pm 5 Ma and 2087 $\pm 9 \mathrm{Ma}$ [26]. In the Lüliang Mountains, the 2063 Ma Daorengou quartz monzonite and the 1906 Ma Huijiazhuang porphyritic biotite granite have been considered as the representative magmatic examples for the collisionevolution of the Paleoproterozoic continental margin [45].

There are some different viewpoints about the early Precambrian tectonic evolution of the North China Craton. The divergences especially focused on the tectonic framework and evolution pattern at the end of Paleoproterozoic age. One suggestion is that the North China Craton had experienced the multistage cratonization. After the cratonization at the end of Neoarchean, the North China Craton went through an intensive thermotectonic event. At the Paleoproterozoic around 2.0-1.97 Ga, the area experienced strong contraction. This process finished its second cratonization and formed the Paleoproterozoic central collisional orogens 
at the west, the east and the central areas $[11,17,33,37,46]$. Another representative viewpoint has emphasized the 2.0 Ga events. This event represented the Paleoproterozoic collisions, such as the Ordos basement with Yinshan Block collision at $2.0 \mathrm{Ga}$; the eastern and the western blocks of the North China Craton collision at about $1.85 \mathrm{Ga}$. These two important collisions accomplished the combination of the Columbia supercontinent [10,12,13,16,26-28,47,48].

The ages of magmatic zircons from basement metamorphic rock and zircons from basement granitic gneiss in the drill holes in the Ordos Basin are consistent with the previous magmatic ages from the former studies in adjacent Paleoproterozoic orogen. Therefore, the basement of the Ordos Basin should be similar with adjacent exhumated regions of active tectonic belts, and formed during the largescale granitic emplacement at the Paleoproterozoic age of 2030-2035 Ma. The whole region experienced the intensive metamorphism at about $1850 \mathrm{Ma}$. Regardless of whether the samples from the Khondalite Belt or from the basement of the Ordos Basin, it seems plausible that the Ordos Basin is not a whole piece of the Archean block. The Ordos Basin should be composed of the Paleoproterozoic active belts. In addition, the absence of Mesoneoproterozoic strata in both QI1 and Long1 drill holes suggests a long exhumation and denudation for the Ordos basement after the late Paleoproterozoic age (Figure 2). The Ordos basement was formed from intensive tectonic-magmatic activity at Paleoproterozoic time, however, based on current available data, it is still hard to determine whether the tectonic event was the results of the collision between the Ordos basement and Yinshan block or the collision between the western and eastern blocks of the Ordos Basin. Just based on the isotopic ages, the result of this study is more consistent with the former age of the Yinshan block and the Ordos basement collision. Since the position of drill hole Long1 is closer to the Central Orogenic Belt, more studies are still necessary to clarify all the ambiguity.

\section{Conclusions}

The drill data, from drill holes QI1 and Long1 in the western and eastern Ordos Basin respectively, reveal the existence of the Precambrian Al-rich metamorphic rocks and two-mica granitic gneiss. The zircons from QI1-1 sillimanite-garnet-biotite-plagioclase gneiss have the magmatic ${ }^{207} \mathrm{~Pb} /{ }^{206} \mathrm{~Pb}$ age of $2031 \pm 10 \mathrm{Ma}$, and the zircons from Long1-1 two-mica granitic gneiss have the ${ }^{207} \mathrm{~Pb} /{ }^{206} \mathrm{~Pb}$ age of $2035 \pm 10 \mathrm{Ma}$. The zircons from the sillimanite-garnetbiotite-plagioclase gneiss are mainly of magmatic origin, possibly suggesting a granitic or volcanic- sedimentary terrain source. The approximate consistence in isotopic chronological data between basement metamorphic rock in western Ordos Basin and basement granite in eastern Ordos Basin indicates that the basement of Ordos Basin experienced intensive magmatic activity at the late Paleoproterozoic age. These ages suggest that the basement of Ordos Basin, similar to its adjacent exhumated region, should encounter the Palaeoproterzoic (2030-2035 Ma) active tectonic development and might not be a single whole Archean block.

This work was supported by the National Basic Research Program of Chi$n a(2012 C B 416604$ and 2012CB416603) and the National Natural Science Foundation of China (91114204). Zhao Guochun and two anonymous reviewers are thanked for constructive reviews. Yang Jiaxi and Ren Minghua are also thanked for their language polishing.

1 Zhao G C. Palaeoproterozoic assembly of the North China Craton. Geol Mag, 2001, 138: 87-91

2 Zhang K. Tectonics and Resources of Ordos Fault-Block. Xi'an: Shanxi Science and Technology Press, 1989. 29-100

3 Jia J D, He G Q, Li M S, et al. Structural feature of basement in the Ordos Basin and its control to Paleozoic gas (in Chinese). Geol J Chin Univ, 1997, 3: 144-153

4 Deng J, Wang Q F, Huang D H, et al. Basement evolution of the Ordos Basin and its constraint on cap rock (in Chinese). Earth Sci Front, 2005, 12: 91-99

5 Wang T, Xu M J, Wang L S, et al. Aeromagnetic anomaly analysis of Ordos and adjacent regions and its tectonic implications (in Chinese). Chin J Geophys, 2007, 50: 163-170

6 Wu C H, Li S X, Gao J F. Archean and early Proterozoic metamorphic area of the North China Craton (in Chinese). In: Dong S B, ed. China Metamorphism and Its Relationship with the Crustal Evolution. Beijing: Geological Publishing House, 1986. 53-89

7 Guo Z M, Zhang J, Yu Z P. The evolutional characteristics of structure of the oil and gas bearing areas in Ordos Massif (in Chinese). Petrol Explor Develop, 1994, 21: 22-29

8 Yang J J. Tectonic Evolution and Oil-Gas Reservoirs Distribution in Ordos Basin. Beijing: Petroleum Industry Press, 2002. 23-27

9 Yang H, Xi S L, Wei X S, et al. Evolution and natural gas enrichment of multicycle superimposed basin in Ordos Basin (in Chinese). Chin Petrol Explor, 2006, 17-24

10 Zhao G C. Metamorphic evolution of major tectonic units in the basement of the North China Craton: Key issues and discussion (in Chinese). Acta Petrol Sin, 2009, 25: 1772-1792

11 Zhai M G, Liu W J. Paleoproterozoic tectonic history of the North China Craton: A review. Precambrian Res, 2003, 122: 183-199

12 Zhao G C, Sun M, Wilde S A. Major tectonic units of the North China Craton and their Paleoproterozoic assembly. Sci China Ser DEarth Sci, 2003, 46: 23-38

13 Zhao G C, Cawood P A, Wilde S A, et al. Review of global 2.1-1.8 Ga orogens: Implications for a pre-Rodinia supercontinent. Earth-Sci Rev, 2002, 59: 125-162

14 Wilde S A, Zhao G C, Sun M. Development of the North China Craton during the Late Archaean and its final amalgamation at $1.8 \mathrm{Ga}$ : Some speculations on its position within a global Palaeoproterozoic supercontinent. Gondwana Res, 2002, 5: 85-94

15 Kröner A, Wilde S A, Li J H, et al. Age and evolution of a late Archean to Paleoproterozoic upper to lower crustal section in the $\mathrm{Wu}$ taishan/Hengshan/Fuping terrain of northern China. J Asian Earth Sci, 2005, 24: 577-595

16 Zhai M G. Cratonization and the Ancient North China Continent: A summary and review. Sci China Earth Sci, 2011, 54: 1110-1120

17 Kusky T M, Li J. Paleoproterozoic tectonic evolution of the North China Craton. J Asian Earth Sci, 2003, 22: 383-397

18 Wan Y S, Song B, Liu D Y, et al. SHRIMP U-Pb zircon geochronology of Palaeoproterozoic metasedimentary rocks in the North China Craton: Evidence for a major Late Palaeoproterozoic tectonothermal event. Precambrian Res, 2006, 149: 249-271

19 Williams I S. U-Th-Pb geochronology by ion microprobe. Reviews in 
Economic Geology, 1998, 7: 1-35

20 Song B, Zhang Y H, Wan Y S, et al. Mount making and procedure of the SHRIMP dating (in Chinese). Geol Rev, 2002, 48(Suppl): 26-30

21 Black L P, Kamo S L, Allen C M, et al. TEMORA 1: A new zircon standard for Phanerozoic U-Pb geochronology. Chem Geol, 2003, 200: $155-170$

22 Ludwig K R. SQUID 1.02: User's Manual. Berkeley Geochronology Center. Special Publication, 2001, No. 2

23 Ludwig K R. User's Manual for Isoplot 3.00. A Geochronological Toolkit for Microsoft Excel. Berkeley Geochronology Center. Special Publication, 2003, No. 4a

24 Stacey J S, Kramers J D. Approximation of terrestrial lead isotope evolution by a two-stage model. Earth Planet Sci Lett, 1975, 26: 207-221

25 Wan Y S, Liu D Y, Yin X Y, et al. SHRIMP geochronology and Hf isotope composition of zircons from the Tiejiashan granite and supracrustal rocks in the Anshan area (in Chinese). Acta Petrol Sin, 2007, 23: 241-252

26 Wilde S A, Zhao G C, Wang K, et al. First SHRIMP zircon U-Pb ages for Hutuo Group in Wutaishan: Further evidence for Palaeoproterozoic amalgamation of North China Craton. Chin Sci Bull, 2004, 49: $83-90$

27 Xia X P, Sun M, Zhao G C, et al. LA-ICP-MS U-Pb geochronology of detrital zircons from the Jining Complex, North China Craton and its tectonic significance. Precambrian Res, 2006, 144: 199-212

28 Xia X P, Sun M, Zhao G C, et al. U-Pb and Hf isotopic study of detrital zircons from the Wulashan khondalites: Constraints on the evolution of the Ordos Terrane, Western Block of the North China Craton. Earth Planet Sci Lett, 2006, 241: 581-593

29 Liu S, Zhao G C, Wilde S A, et al. Th-U-Pb monazite geochronology of the Lüliang and Wutai Complexes: Constraints on the tectonothermal evolution of the Trans-North China Orogen. Precambrian Res, 2006, 148: 205-224

30 Zhao G C, Wilde S A, Sun M, et al. SHRIMP U-Pb zircon ages of granitoid rocks in the Lüliang Complex: Implications for the accretion and evolution of the Trans-North China Orogen. Precambrian Res, 2008, 160: 213-226

31 He Y, Zhao G C, Sun M, et al. SHRIMP and LA-ICP-MS zircon geochronology of the Xiong'er volcanic rocks: Implications for the Paleo-Mesoproterozoic evolution of the southern margin of the North China Craton. Precambrian Res, 2009, 168: 213-222

32 Liu C, Zhao G C, Sun M, et al. U-Pb and Hf isotopic study of detrital zircons from the Hutuo Group in the Trans-North China Orogen and tectonic implications. Gondwana Res, 2011, 20: 106-121

33 Zhai M, Li T S, Peng P, et al. Precambrian key tectonic events and evolution of the North China Craton. Geol Soc Lond Spec Publ, 2010, 338: 235-262

34 Peng P, Guo J H, Zhai M G, et al. Paleoproterozoic gabbronoritic and granitic magmatism in the northern margin of the North China Craton: Evidence of crust-mantle interaction. Precambrian Res, 2010, 183:
$635-659$

35 Liu C H, Zhao G C, Sun M, et al. U-Pb and Hf isotopic study of detrital zircons from the Yejishan Group of the Lüliang Complex: Constraints on the timing of collision between the Eastern and Western Blocks, North China Craton. Sediment Geol, 2011, 236: 129-140

36 Geng Y S, Zhou X W, Wang X S, et al. Late-Paleoproterozoic granite events and their geological significance in Helanshan area, Inner Mongolia: Evidence from geochronology (in Chinese). Acta Petrol Sin, 2009, 25: 1830-1842

37 Guo J H, Zhai M G, Xu R H. Timing of the granulite facies metamorphism in the Sanggan area, North China Craton: Zircon U-Pb geochronology. Sci China Ser D-Earth Sci, 2001, 44: 1010-1018

38 Zhong C T, Deng J F, Wan Y S, et al. Magma recording of Paleoproterozoic orogeny in central segment of northern margin of North China Craton: Geochemical characteristics and zircon SHRIMP dating of S-type granitoids (in Chinese). Geochimica, 2007, 36: 585-600

39 Liu J, Li Y, Ling M X, et al. Chronology and geological significance of the basement rock of the giant Bayan Obo REE-Nb-Fe ore deposit (in Chinese). Geochimica, 2011, 40: 209-222

40 Zhao G C, Wilde S A, Guo J H, et al. Single zircon grains record two Paleoproterozoic collisional events in the North China Craton. Precambrian Res, 2010, 177: 266-276

41 Yin C Q, Zhao G C, Sun M, et al. LA-ICP-MS U-Pb zircon ages of the Qianlishan Complex: Constraints on the evolution of the Khondalite Belt in the western block of the North China Craton. Precambrian Res, 2009, 174: 78-94

42 Yin $\mathrm{C} \mathrm{Q}$, Zhao G C, Guo J H, et al. U-Pb and $\mathrm{Hf}$ isotopic study of zircons of the Helanshan Complex: Constraints on the evolution of the Khondalite Belt in the western block of the North China Craton. Lithos, 2011, 122: 25-38

43 Xia X P, Sun M, Zhao G C, et al. Paleoproterozoic crustal growth in the Western Block of the North China Craton: Evidence from detrital zircon $\mathrm{Hf}$ and whole rock $\mathrm{Sr}-\mathrm{Nd}$ isotopic compositions of the Khondalites from the Jining Complex. Am J Sci, 2008, 308: 304-327

44 Li X P, Yang Z Y, Zhao G C, et al. Geochronology of khondalite-series rocks of the Jining Complex: Confirmation of depositional age and tectonometamorphic evolution of the North China Craton. Int Geol Rev, 2011, 53: 1194-1211

45 Geng Y S, Yang C H, Wan Y S. Paleoproterozoic granitic magmatism in the Lüliang area, North China Craton: Constraint from isotopic geochronology (in Chinese). Acta Petrol Sin, 2006, 22: 305-314

46 Zhai M G, Peng P. Paleoproterozoic events in the North China Craton (in Chinese). Acta Petrol Sin, 2007, 23: 2665-2682

47 Santosh M, Wilde S A, Li J H. Timing of Paleoproterozoic ultrahigh-temperature metamorphism in the North China Craton: Evidence from SHRIMP U-Pb zircon geochronology. Precambrian Res, 2007, 159: 178-196

48 Xia X P, Sun M, Zhao G C, et al. U-Pb and Hf isotopic study of detrital zircons from the Lüliang khondalite, North China Craton, and their tectonic implications. Geol Mag, 2009, 146: 701-716

Open Access This article is distributed under the terms of the Creative Commons Attribution License which permits any use, distribution, and reproduction in any medium, provided the original author(s) and source are credited. 